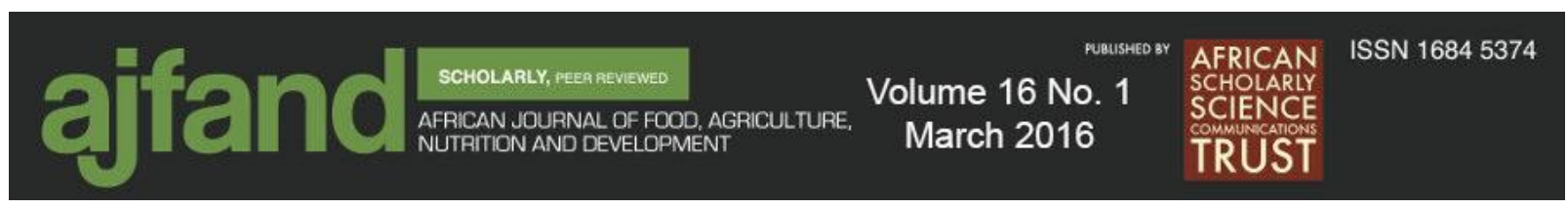

DOI: 10.18697/ajfand.73.15255

\title{
A PRELIMINARY SURVEY OF ANIMAL HANDLING AND CULTURAL SLAUGHTER PRACTICES AMONG KENYAN COMMUNITIES: POTENTIAL INFLUENCE ON MEAT QUALITY
}

\section{Lokuruka MNI ${ }^{*}$}

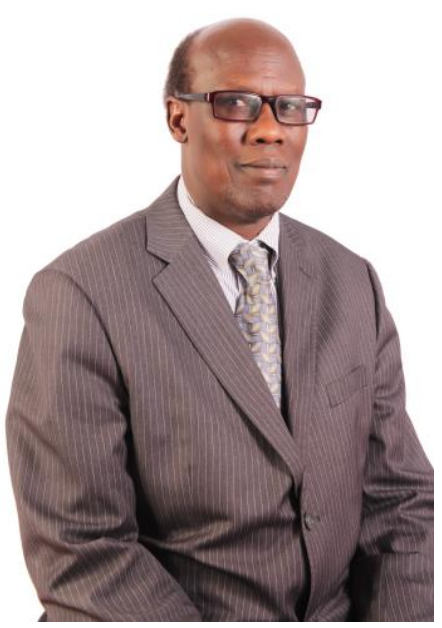

Michael Lokuruka

*Corresponding author email: mlokuruka@gmail.com

${ }^{1}$ Associate Professor of Food Science, Department of Food Science and Nutrition, Karatina University, and

Commissioner, Public Service Commission, Nairobi 


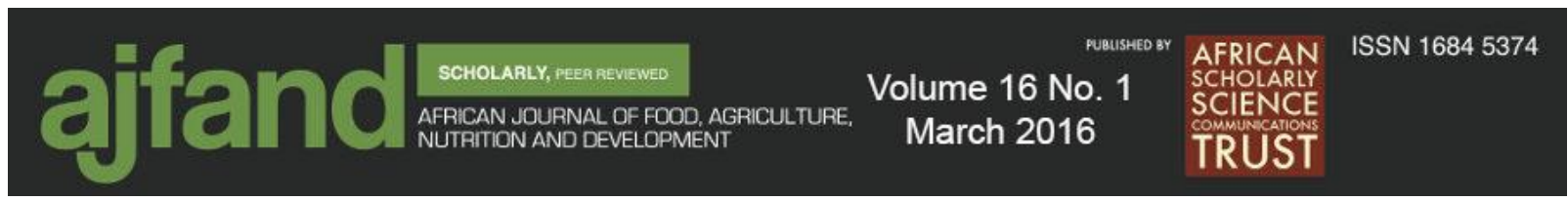

\section{ABSTRACT}

Kenya is composed of over 40 ethnic communities who practice varied methods of animal handling and slaughter. Socio-cultural and religious traditions have the potential to influence animal handling and slaughter practices. These influences have, however, not been documented in the literature as far as the author is aware. Also, the literature has documented the connection between the manner of animal treatment and meat quality, but this is rarely discussed in the literature in Kenya; this connection is important as it informs modern meat trade practices by Kenyans as they trade in the global arena. This survey aimed to mainly establish and document the animal slaughter practices among Kenyan communities, and, to also highlight any current provisions related to meeting modern animal welfare requirements, animal handling procedures in the meat trade and discuss their potential influence on meat quality available in commerce in Kenya. This preliminary study surveyed the slaughter practices among 10 different Kenyan communities through a semi-structured questionnaire, focus group discussions and individual interviews. The survey demonstrated that different Kenyan communities practice varied methods of animal slaughter depending on whether the animal being slaughtered is for public feasting, domestic consumption or commercial merchandizing. The Kenyan communities surveyed in this study depend mainly on males to slaughter livestock for females preparing it for domestic use using a number of instruments and methods. For small stock for domestic consumption, females may slaughter the animal except for Muslims whose males have to slaughter the animal with a special knife (a Khalef) according to Muslim rites to render it Halal. Large stock is invariably slaughtered by males irrespective of the community, and the manner of use of the carcass. Gender, age, religion, community and the size of the animal were the major determinants of the method of animal slaughter. The animal welfare issues highlighted in the survey and related to the handling and slaughter of livestock have important implications for meat quality during commercial merchandizing. There is an apparent need to provide education to herders, livestock handlers, employees and management in the livestock industry in Kenya on the relationship between animal welfare requirements, animal handling procedures and meat quality. Such awareness can potentially improve the quality and economic value of the meat available in commerce.

Key words: Kenya, animal welfare, handling, slaughter practices, meat quality 


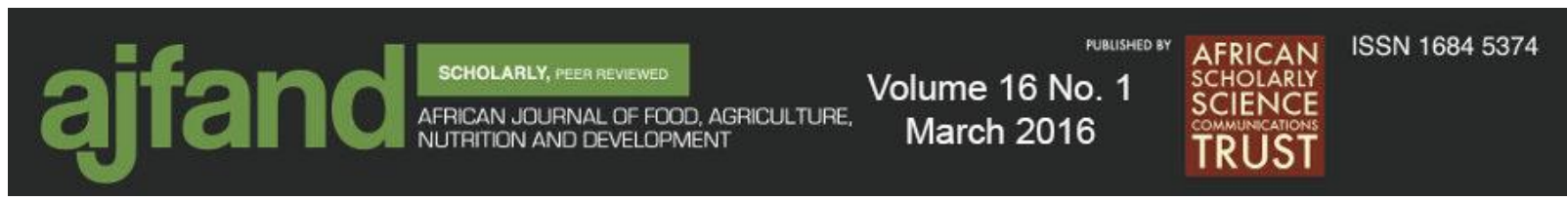

\section{INTRODUCTION}

Kenya has an estimated population of over 41 million people who are made up of about 42 distinct communities [1]. Its population is made up of about $47.7 \%$ Protestants, $28.4 \%$ Roman Catholics, 9\% of Indigenous beliefs, 11.2\% Muslims, 1\% Bahais, 0.04\% Hindu and about $2.6 \%$ of other faiths [2].

More than $80 \%$ of the country's land mass is made up of what is often referred to as the arid and semi-arid lands (ASAL), which is where about $30 \%$ of the country's population lives [2]). The ASAL regions are characterized by a sparse human population distribution, low and unpredictable rainfall, usually 5-300 mm/year [3]. More than 70\% of the country's livestock population is in the ASAL and most are reared by nomadic pastoralist communities including the Boran, Gabbra, Rendille, various Somali subgroups, the Samburu, Turkana, Maasai, Pokot, and the Orma. The country's livestock population is composed mainly of goats, sheep, cattle, camels, chicken, pigs and donkeys. Pigs are reared for commerce by a small number of farmers and usually within a $100-\mathrm{km}$ radius of the major cities. To meet the food acceptability and religious requirements of the Kenya Muslims, the animal for food must be slaughtered by a Muslim to make its meat Halal. Poultry are mainly the traditional breeds of chicken that are kept using low-cost range management systems to supply subsistence food needs. However, commercial poultry keeping based on exotic breeds is an important economic activity in the country. Chicken eggs are an important item of commerce and food in Kenya. The population of geese, ducks and ostriches is insignificant. The beef cattle kept on private ranches in the ASAL zones, supply a significant amount of beef for consumers in major urban centres in the country. In the 2009 National Population and Household Census, Kenya was reported to have 3,355,407 exotic cattle, 14,112,367 indigenous cattle, 17,129,606 sheep, 27,740,153 goats and 2,971,111camels [2]. Other animals counted in the 2009 Population and Household Census included 334,689 pigs, 25,756,487 indigenous chicken, 6,071,042 commercial chicken, and 1,832,519 donkeys. The former Western Province with 16\% of the total national population of chicken (both indigenous and commercial), leads in this livestock category. The Rift Valley region, where the Turkana, Maasai, Pokot and Samburu pastoralists live had $42.8 \%$ of the total national cattle population, $28.8 \%$ of the national indigenous cattle population and $54.6 \%$ of the Rift Valley region's total cattle population. The two regions of Rift Valley and Northeastern had 58.7, 70.5, 77.9, and $89.8 \%$ of the total national cattle, goat, sheep, and camel population, respectively [2]. Northeastern Province had the lowest pig population which stood at only 68 pigs, representing $0.02 \%$ of Kenya's pig population according to the 2009 Population and Household census, as it has the second highest Muslim population after Kenya's Coastal strip [2]. The production of total meat, mutton and goat meat, poultry, pork, milk and eggs in Kenya in 2002 stood at 452.6x103 metric tons (mT), 5.7x103 mT, 54x103 MT, 2841x106 litres and 60.6 million eggs [4], respectively, with most of the beef, goat meat and mutton coming from the ASAL. The per capita production of total meat, beef, mutton and goat meat, poultry and milk stood at 14.3 $\mathrm{kg} / \mathrm{yr}, 10 \mathrm{~kg}, 1.0 \mathrm{~kg}$ and 90 liters/yr in 2002 [4]. For the purpose of this article, small stock refers to goats, and sheep, while large slaughter stock refers to donkeys, cattle, and camels. In this article also, no discussion will be made specifically on chicken or other 


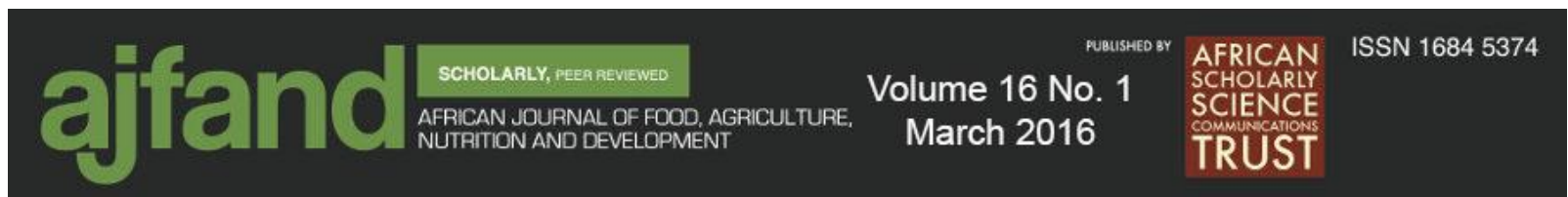

poultry, fish and related sources of meat. The text focuses on meats in general and without emphasis on the white or red type. It is a mini-review of the literature on animal welfare requirements, animal handling and meat quality as it applies to the Kenyan situation.

\section{METHODS AND PROCEDURES}

A semi-structured questionnaire to establish the manner of animal slaughter in 10 Kenyan communities was administered to groups of 10-15 members of a community as focus groups. The communities surveyed were: nomadic pastoralists-the Turkana, Boran, Samburu, Pokot, Somali, and the Maasai, while the farming communities surveyed were the Kuria, Luo, Kalenjin, and Kikuyu. The total number of respondents who took part in the survey was 124. A few individual interviews were also conducted with a few members of some of the communities. The questionnaire and focus group discussions also set out to establish the extent of knowledge of the relationship of animal welfare and handling procedures, and slaughter practices as they would influence meat quality.

\section{Limitations of the study}

1. A small sample of communities was surveyed for their slaughter practices (10 out of a possible 42), although the author believes the slaughter and animal handling practices of those communities who were not surveyed would not have been different from the findings of the study.

2. The influence of religion on slaughter practices was documented only for the Muslims as it proved difficult to interview believers of other faiths.

3. More nomadic communities were surveyed than the farmer-communities; this was because the nomadic pastoralists provide most of the slaughter stock and keep most of the livestock population of Kenya, except for pigs and poultry.

\section{RESULTS}

1. For the Turkana and Pokot communities, the spear is reserved for use by adult, initiated and circumcised males, while the knife is mandatorily used by females and young uncircumcised males for animal slaughter. Where a Muslim has to share the meat, they let the male Muslim slaughter the animal. The Turkana and Pokot males slaughter the animal for public feasts while females can use the kitchen knife to slaughter small stock for domestic consumption. However, for large stock such as cattle, donkey and the camel, males slaughter them due to their sizes which females may find difficult to manage.

2. In the Maasai and Samburu communities, the club is traditionally reserved for use by males, while the knife is used by females irrespective of age and marital status. The male and female gender, however, do not share the meat slaughtered by these procedures in the traditional set up. However, similar to other communities, these taboos are breaking down and are no longer adhered to in contemporary society. The use of a club for small animal slaughter is common among the Maasai and Samburu youth although the un-initiated Turkana youth may also use the same technique when they are far away from the homestead and do not possess the wrist knife. 


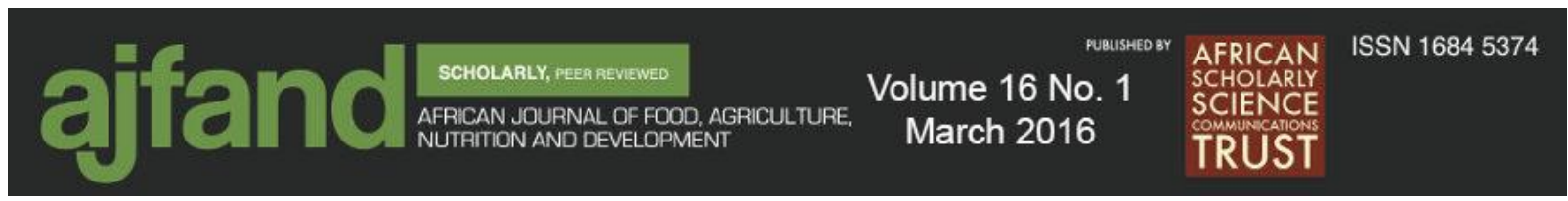

3. Among the Boran, any slaughter process whether in the home or at a public party is done traditionally by adult males.

4. For the Somali and Boran Muslims, only males slaughter stock irrespective of animal size and whether the animal is for use in public feasting, domestic or for commerce. The same is true of Muslims from other communities also as established in this survey

5. For the Kuria, Luo, Kalenjin and Kikuyu who are mainly farmers, males slaughter stock but not as a strict requirement. Occasionally the females among the Kuria can smother a small animal to death instead of using the kitchen knife for slaughter.

6. Kenyan Christians did not demonstrate special preference for any particular method of animal slaughter.

7. Knowledge of the links of animal welfare requirements, animal handling procedures and meat quality were rarely a consideration among the 10 Kenyan communities when slaughtering animals even for commerce.

\section{DISCUSSION}

\section{Livestock handling and its relationship to animal welfare}

In 1866, the American Society for the Prevention of Cruelty to Animals was established [5]. Following that, similar societies in other parts of the world including Kenya were formed in order to enforce humane animal care as part of animal welfare services. The Kenya Society for the Protection and Care of Animals was started in 1910 in Mombasa as the East African Society for the Prevention of Cruelty to Animals (EASPCA), through the influence of the British Colonizers [6]. The EASPCA was later renamed the Kenya Society for the Prevention of Cruelty to Animals (KSPCA). Despite its long time of existence, the KSPCA is largely ineffective as it is underfunded. The idea behind animal welfare is that animals which provide humans with one of the most nutritious and wellbalanced foods available, should be taken care of to remain in good health and treated kindly at all times, and not suffer pain at slaughter [7]. Due to the need to treat animals kindly before slaughter, the meat industry coined the term "harvest" to replace the word "slaughter". Although the term "harvest" is not used throughout this text, the reader should, however, be aware that the humane treatment of animals results in the conversion of a live, well cared for, healthy and contented animal, into a delicious meal in the form of meat. Generally, live animals are used for various non-religious and religious purposes. They serve as items of dowry during traditional weddings, gifts among bondfriends and relatives as among pastoralist communities of the Turkana and Maasai of Kenya, and the Jiye and Karamoja of Uganda [8], mass offerings for religious sacrifices in countries such as India and Nepal [9] and as slaughter stock for domestic, public feasts and funeral rituals [Table 1]. In Kenya for non-commercial and small trade, and where distances to abattoirs are manageable $(<50 \mathrm{~km})$, slaughter stock is normally driven on foot to their place of sale and/or slaughter. However, where large numbers are moved (irrespective of distance), transport in open trucks to market and/or slaughter points is the commonest method of animal transfer. The animals should normally be inspected for infections such as foot and mouth disease and contagious bovine pleuropneumonia (CBPP), among other diseases at the point of loading on trucks and a certificate by a veterinarian is usually adequate assurance of freedom from infectious and zoonotic 


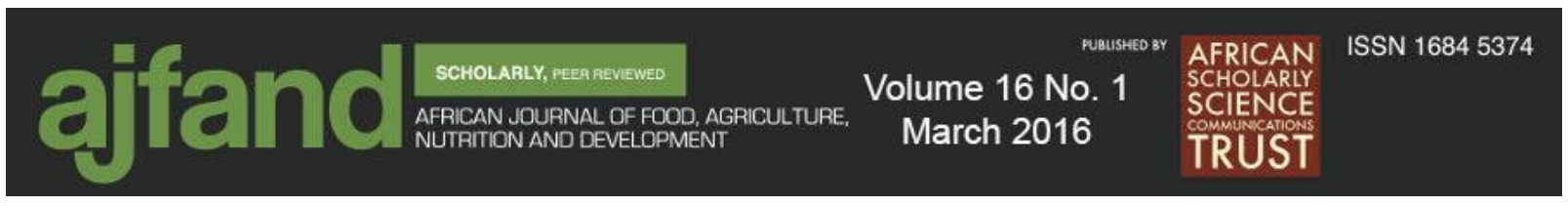

diseases according to the applicable ante-mortem inspection regulations [10]. However, this situation applies to animals slaughtered in urban areas and cities where the services of meat inspectors and veterinary personnel are available; in Kenya's rural areas, consumers are likely to be treated to unsafe meat thus exposing them to infections and sometimes fatalities, where diseases such as anthrax are involved. Most of the traditional methods of animal handling, and slaughter highlighted in this survey apply largely in the rural areas, but also in urban areas to a considerable extent despite the townspeople buying their meat from established butcheries and slaughter houses, where the Muslim method of slaughter is the norm rather than the exception. When ante-mortem inspection is carried out, it is not normally necessary for the inspector to expose any real disease at inspection, but even disease symptoms which may influence the general health of the bird or animal count; the presence of notifiable infectious disease or symptoms which may suggest that such disease is developing, or emaciation, dirty ruffled feathers in poultry, abscesses and infected wounds, discoloured and edematous skin or comb in poultry, diarrhoea, gaping or sneezing, discharge from eyes and or nostrils, lameness and central nervous system disorder can make the inspector declare the animal unfit for human consumption [10]. Generally, the purpose of the ante-mortem inspection is to provide an animal that is reasonably fit, and that is likely to provide wholesome and safe food, but not to grade the animal [10]. The open trucks that normally carry livestock in Kenya do not have any special equipment to cater for modern animal welfare requirements. Furthermore, the animals are usually overcrowded and are often transferred over long distances from the ASAL regions to Nairobi over 3-4 days, often without rest, feed and water. The overcrowding in trucks and the lack of rest for animals before arrival at slaughter points goes against modern animal welfare requirements [11, $12]$. European Union (EU) regulations require that journeys should normally not exceed 8 hours otherwise the animals should be offloaded, rested for 24 hours, fed and given water to drink [13]. The EU regulation requires that transport vehicles must be fitted with equipment of the highest quality, including a temperature monitoring system (mechanical ventilation, temperature recording, and with warning system capability) fitted in the driver's cabin, including permanent access to drinking water. For Kenya, these would be ideal requirements but are currently far from attainable. In the EU, the transport of certain animals is also prohibited. This applies to very young animals (calves of less than 10 days, pigs of less than three weeks and lambs of less than a week), except where the journey does not exceed $100 \mathrm{~km}$. The regulation also prohibits transport of females in the last stages of gestation and during the first week after giving birth [13]. Kenya's current animal care and transport regulations do not come anywhere near to these rules as far as the author is aware. In addition, the EU animal transport condition for horses on long journeys requires the use of individual stalls. The author has observed horses being transported in Kenya in poorly designed open trucks. In terms of journey times, the EU regulation provides for different times depending on the type of animal: unweaned animals, i.e. animals still drinking milk ( 9 hours of travel, followed by one hour's rest to enable the animals to drink, followed by a further 9 hours of travel), pigs ( 24 hours of travel, provided there is continuous access to water), horses ( 24 hours of travel, with access to water every 8 hours), cattle, sheep and goats (14 hours of travel, followed by one hour's rest to enable the animals to drink, followed by a further 14 hours of travel) [13]. The above sequences may be repeated provided the animals are unloaded, fed, 


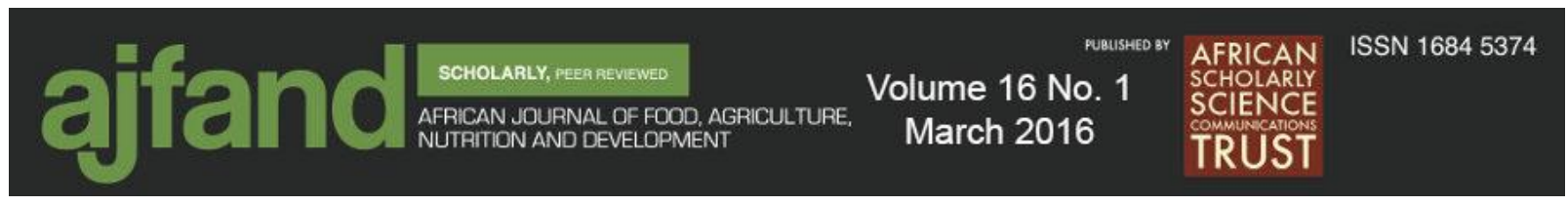

watered and rested for at least 24 hours at an approved control post. This is a far contrast from the current conditions of transport common on Kenya's roads where animals can be transported say from Lokicokkio in Turkana in the north of the country to Kitale in the middle of the country with only two stops over a journey of $500 \mathrm{~km}$. The stops would be in Lodwar a 240-km trip from Lokicokkio and then Kitale a further $300 \mathrm{~km}$ away. Even then, the animals are normally not off-loaded, not fed or even given water to drink and may be rested for 4-10 hours to allow the crew some rest, rather than the animals. The results of such poor animal treatment are economic losses that are not desirable when high quality meat is the expectation on slaughter and commercial sale [14]. Although the withdrawal of water and feed during the period of transfer may reduce gut contamination of the carcass after slaughter and during handling, it may lead to unwarranted weight loss of the carcass, resulting in economic loss to the trader [14]. In an experiment with pigs, it was demonstrated that transportation is a complex stressor, which negatively impacted the health and welfare of weaned pigs. Transport duration and withdrawal of feed and water are two factors that were shown to potentially adversely affect the welfare of pigs transported at weaning [14]. In this study, the effect of a 32-hour transport period and the provision of feed and water on the welfare of weaned pigs were investigated using a multi-disciplinary approach. The results were such that body weight decreased in weaned pigs over time and this response was exacerbated by exposing pigs to a 32-hour transport period and withdrawing feed and water. The greatest changes in body weight loss were observed after 8 hours of transport or weaning for some unexplained reason. Furthermore, the neutrophil to lymphocyte ratio $(\mathrm{N}: \mathrm{L})$ stress measure was elevated in pigs in response to an 8 -hour transport period or 8 hours after weaning alone. With the exception of weaned pigs provided with feed and water, transported and weaned pigs continued to be different from control pigs until 16 hours after weaning or exposure to a 16-hour transport period. These findings suggest that pigs experience an acute stress response due to long transport and weaning, but these two stressors do not appear to be additive. Overall, transportation had a negative effect on performance, physiology and behaviour of weaned and transported pigs, especially if not provided with feed and water for more than 24 hours [14]. Similar findings were also shown on cattle transported poorly, denied feed and water [15]. Animal welfare requirements such as feeding before slaughter, providing a specific period of fast (depending on the animal), providing some rest to animals during transfer and giving drinking water ad libitum, can reduce economic losses and improve the quality of meat after harvest and at the point of sale [16]. Besides the overcrowding and poor treatment during transfer as is evident in the Kenyan livestock trade situation, animals are often beaten resulting in bruises to the skin and internal bleeding even before slaughter. Such inhumane animal treatment is manifest as bloody meat, torn hides, which may result in downgrading of the meat cuts and hides and eventually as economic loss to the farmer and trader [17]. In modern animal harvest practices, employees should be educated to understand the proper sequence of harvest activities and know what needs to be done at each stage of animal handling and why [18]. Further, and for the herders, the livestock trader and meat industry management personnel, understanding the influence on meat quality of poor treatment of the live animal is critically important, especially where consumers demand animal welfare issues are addressed pre-slaughter [19]; for meat industry personnel, the influence of animal handling practices on meat quality and the potential prices of the various meat cuts during 


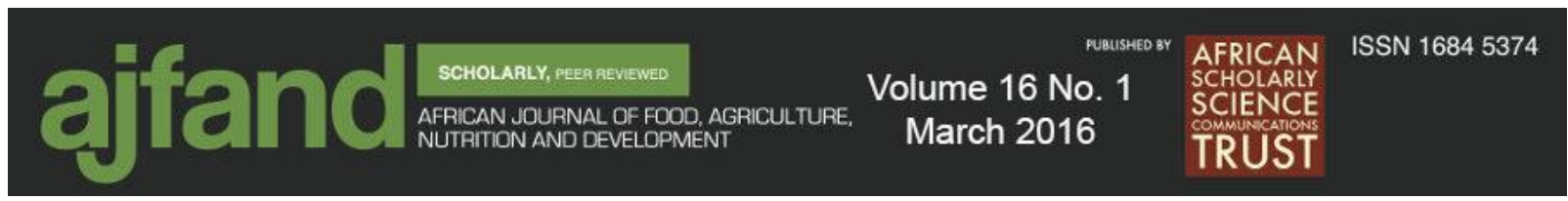

merchandizing should be an important aspect of training. Meat industry practitioners believe that proper handling of meat animals can improve productivity, quality and profitability, so they emphasize that it is good business to do it right [20].

\section{Animal welfare issues and meat quality}

Meat grading of the carcass is normally done postmortem. Although meat grading is essentially voluntary, its purpose is to guarantee acceptability of the carcass to the buyer, who pays for the service [21]. Grading essentially involves distinguishing carcasses by class and maturity [5]. Grade is also determined by the position of the cut on the carcass and the amount of lean meat on the cut. Factors that are considered in the determination of meat quality include colour, marbling and the tenderness of the lean flesh [22]. The age of the animal affects the colour and texture of the meat, while the long term plane of nutrition affects all the three characteristics [5, 22]. Poor handling of an animal preslaughter may alter the colour and texture of the meat but marbling is not normally affected. In long-term stressed animals, a pH around 6.0 or higher is common [23, 24], while a low $\mathrm{pH}$ of 5.4-5.7 results from short-term stress in all species of animals [25]. The result of the high $\mathrm{pH}$ is a change in the colour, tenderness and the water holding capacity of the resulting meat [26], but not the overall meat quality [27]. A high pH can lead to the proliferation of micro-organisms thus affecting the keeping period of the meat. Dark-cutting meat and the high $\mathrm{pH}$ results from a reduced glycogen content of the lean meat at the time of harvest [5]. This may be due to fasting the animal for more than a day before harvest, excessive stress due to poor treatment of the animal during long and poor transport conditions, or severe struggling by animals prior to death [28], a situation that relates to poor animal welfare provisioning and handling. It is normally recommended that animals except poultry are fasted for about 24 hours (usually about 12 hours for poultry) before harvest in order to maintain the desirable cherry red colour and therefore the prime quality of meat, while supplying drinking water ad libitum to reduce weight loss from dehydration [5].

Stressing the animals during transport and at handling pre-slaughter leads to exhaustion of the glycogen in muscle, which results in darker meat (dark, firm and dry meat, DFD) and in hogs to pale, soft and exudative (PSE) pork [5, 29]. Such pork is whitish in colour and loose in texture. To save glycogen depletion and obtain good quality meat requires that the animal is calmed and treated well before harvest [30]. The same defects can also be caused by fasting and withdrawal of feed for more than a day before harvest as discussed earlier. A combination of both feed withdrawal and stress pre-slaughter can therefore aggravate the defect in the resulting meat, a situation that should be avoided if high quality, good colour meat is desired [29]. The length of the fasting period before slaughter will determine the amount of glycogen available for conversion to lactic acid postmortem; a short period of waiting results in a $\mathrm{pH}$ below 7.0, a more desirable muscle colour and increased water holding capacity [31], thus maintaining a high degree of acceptability of the meat to a purchaser. Normally, animals are expected to weigh less immediately prior to harvest than at purchase, since they "shrink" in transit. Animals standing in yards awaiting harvest rarely gain back to their purchase weight, even if they have feed and drinking water before slaughter. Stress can contribute to weight loss because of being in new environments, thirst and fatigue, adverse handling, adverse 


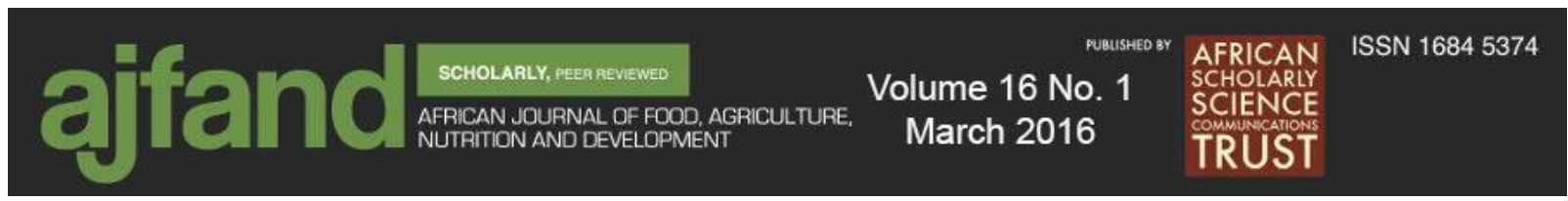

weather conditions in lairage. as animals wait for their turn at the slaughter cell [32]. On immobilization, animals should be held gently and in quiet surroundings prior to slaughter. However, animals that are restrained before slaughter using a knife or a spear as in most traditional slaughter practices as shown in this survey are usually stressed, struggle a lot and potentially reduce in glycogen, resulting in unacceptable meat quality. The use of the rapid stunning methods such as the stunning bolt minimize the defect, although electrical stunning may better for higher quality meat products [29]. However, if a 20-30 minute period of calm is allowed before slaughter and the traditional slaughter method with a knife is short (less than 10 seconds), the loss in glycogen and its adverse effect on meat quality can be minimized [33]. This situation may be realized where a special sharp knife (the Khalef) is used for slaughter as in the traditional Jewish Kosher or Halal slaughter method by a Muslim; calming the animal and resting it before slaughter, speed in the slaughter process contribute to the good result manifested as desirable quality meat [34].

The completeness of bleeding is another factor worth considering in any discussion on meat quality. Incomplete bleeding may leave much blood in muscles thereby discolouring the meat and consequently downgrading it [35]. However, complete blood removal is rarely achieved. Also, blood is an excellent medium for microbial growth and oxidation of meat leading to deterioration, as complete bleeding is almost impossible to attain [36]. As much removal of blood is therefore a major requirement for the retention of the desirable quality in meat.

In consideration of the need to treat animals humanely, animal handlers, farmers, traders and abattoirs are advised to provide the following: a) spacious, clean and airy accommodation on the farm and in transit to market, b) adequate, appropriate and timely treatment of sick animals on the farm to forestall the spread of zoonoses, c) handling the animals humanely on the farm and just before slaughter without undue beating and rough treatment, d) some rest periods, feeding and watering during transport and pre-slaughter, e) ante-mortem inspection before animal harvest, avoidance of restraining and excitation of the animals before slaughter by ensuring slaughter is done in a quiet and calm environment, f) modern methods of anaesthesia such as taking them through carbon dioxide chambers before slaughter. The result of the harvest of such stock is a diseasefree, hygienic carcass of high keeping and eating quality.

\section{CONCLUSION}

The study has established that for most Kenyan communities, the method of animal slaughter in the home and for public feasts and rituals is different and is based on the gender of the butcher and often on the size of the animal. A Muslim is always given preference to slaughter an animal while a Christian does not have any particular preference for the method of animal slaughter. The Kenyan communities who took part in this survey did not take into consideration modern animal welfare practices in the handling and slaughter of livestock at home, public feasts, trade or at funeral rituals. 


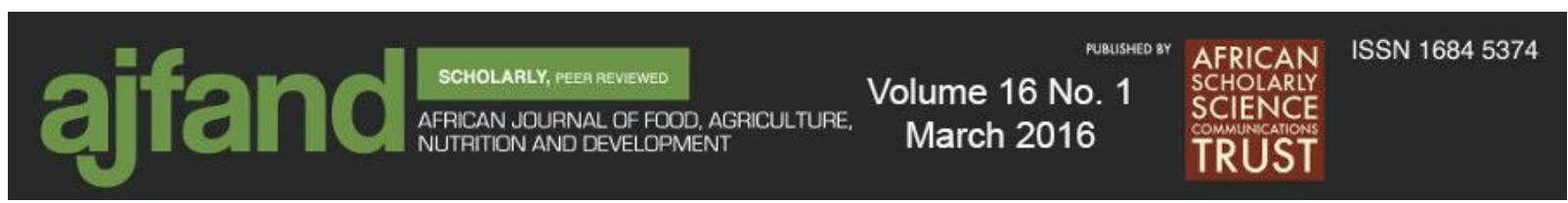

\section{RECOMMENDATIONS}

The livestock farmer, trader, livestock handler and butcher in Kenya require education on animal welfare issues in view of the globalization of animal welfare issues in international meat trade. Trade in livestock meat should emphasize good animal handling procedures in order to produce high quality meat for high economic returns.

\section{ACKNOWLEDGEMENTS}

I acknowledge the following persons for accepting to be interviewed on the slaughter practices of their community and religious faith.

Professor Abdi Y. Guliye and Dr. Noor Mohammed-Department of Animal Sciences, Egerton University; Iddi Lokono-Egerton University; Molid Fulano, Ewaso, Isiolo County; Madame Nauyongorot Ipat and Loilyong Napoo-Lodwarr, Turkana Central subcounty; Erukut Iwaate-Turkana west sub-county; Korir Koske-Eldoret, Uasin Gishu County; Mwangi Njoroge-Kiambu town, Kiambu County; Mrs. Maureen Karanja, Sheikh Khalid and Jecinta Mogaka-Nakuru town, Nakuru County; Omondi Opuka, Joash Wepukhulu-Kisumu, Kisumu County and Lepuchirit Lemiu-Maralal town, Samburu County. I appreciate with immeasurable gratitude the many interviewees who willingly took part in the study and who shared much of the knowledge documented herein. 


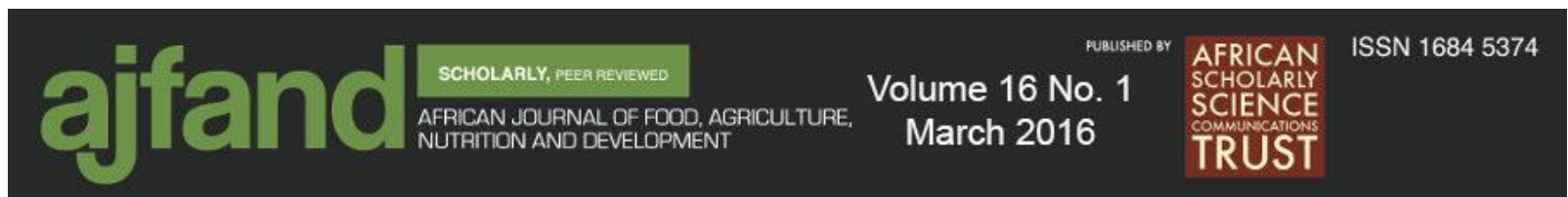

Table 1: Animal handling and slaughter practices among Kenyan Communities

\begin{tabular}{|c|c|c|c|}
\hline \multirow{2}{*}{$\begin{array}{l}\text { Kenyan } \\
\text { Community }\end{array}$} & \multicolumn{2}{|c|}{ Methods of slaughter } & \multirow{2}{*}{$\begin{array}{l}\text { Nature of } \\
\text { function }\end{array}$} \\
\hline & By females & By males & \\
\hline Turkana $^{1}$ & $\begin{array}{l}\text { Females usually } \\
\text { slaughter small stock } \\
\text { for food by cutting } \\
\text { through the jugular } \\
\text { vein with a kitchen } \\
\text { knife }\end{array}$ & $\begin{array}{l}\text { Spearing through the } \\
\text { right ribcage-a silent } \\
\text { prayer may be said by } \\
\text { adult male slaughtering } \\
\text { the animal }\end{array}$ & $\begin{array}{l}\text { Domestic and } \\
\text { communal feast }\end{array}$ \\
\hline Pokot $^{1}$ & $\begin{array}{l}\text { Females usually } \\
\text { slaughter small stock } \\
\text { for food by cutting } \\
\text { through the jugular } \\
\text { vein with a kitchen } \\
\text { knife but for animal } \\
\text { used at home }\end{array}$ & $\begin{array}{l}\text { A male pierces with a } \\
\text { spear through right } \\
\text { ribcage or cuts through } \\
\text { jugular vein }\end{array}$ & $\begin{array}{l}\text { Domestic and } \\
\text { communal feast }\end{array}$ \\
\hline Samburu $^{2}$ & $\begin{array}{l}\text { Cuts the jugular vein } \\
\text { with a kitchen knife }\end{array}$ & $\begin{array}{l}\text { A male hits animal with } \\
\text { a wooden club on poll } \\
\text { or pierces the Medulla } \\
\text { oblangata with a sharp } \\
\text { metallic object }\end{array}$ & $\begin{array}{l}\text { Communal and } \\
\text { domestic feast }\end{array}$ \\
\hline Maasai $^{2}$ & $\begin{array}{l}\text { Females cut jugular } \\
\text { vein with a kitchen } \\
\text { knife }\end{array}$ & $\begin{array}{l}\text { A male hits animal with } \\
\text { club on the poll or } \\
\text { pierce the Medulla } \\
\text { oblongata with a sharp } \\
\text { object }\end{array}$ & $\begin{array}{l}\text { Both domestic, } \\
\text { communal and } \\
\text { private (for young } \\
\text { "Moran"-warrior } \\
\text { group) feast }\end{array}$ \\
\hline Boran $^{3}$ & $\begin{array}{l}\text { Cut the jugular vein } \\
\text { of animal for female } \\
\text { users of animal }\end{array}$ & $\begin{array}{l}\text { Cut the jugular vein } \\
\text { (both Muslims and } \\
\text { Christians) }\end{array}$ & $\begin{array}{l}\text { communal \& } \\
\text { domestic feast for } \\
\text { community \& } \\
\text { others }\end{array}$ \\
\hline Somali (Muslims ${ }^{4}$ ) & $\begin{array}{l}\text { Males cut the jugular } \\
\text { vein on behalf of } \\
\text { females, with a } \\
\text { prayer said before } \\
\text { slaughter }\end{array}$ & $\begin{array}{l}\text { Male says prayer and } \\
\text { cuts through the jugular } \\
\text { vein with a Khalef while } \\
\text { facing in the direction of } \\
\text { Mecca }\end{array}$ & $\begin{array}{l}\text { Both communal } \\
\& \text { domestic feast } \\
\text { for Muslim } \\
\text { community \& } \\
\text { others }\end{array}$ \\
\hline Somali (Christians) & $\begin{array}{l}\text { Christian Somali } \\
\text { male cuts the jugular } \\
\text { vein on behalf of } \\
\text { females }\end{array}$ & $\begin{array}{l}\text { Christian Somali male } \\
\text { cuts the jugular vein of } \\
\text { animal }\end{array}$ & $\begin{array}{l}\text { Domestic \& } \\
\text { communal feast } \\
\text { for community } \\
\text { members \& others }\end{array}$ \\
\hline $\begin{array}{l}\text { Muslims }{ }^{4} \text {-all sects, } \\
\text { irrespective of } \\
\text { community }\end{array}$ & $\begin{array}{l}\text { Males cut through } \\
\text { the jugular vein of } \\
\text { animal for female } \\
\text { users of carcass } \\
\text { while facing Mecca }\end{array}$ & $\begin{array}{l}\text { Male says prayer while } \\
\text { facing direction of } \\
\text { Mecca and } \\
\text { simultaneously cuts } \\
\text { jugular vein of animal }\end{array}$ & $\begin{array}{l}\text { Domestic, } \\
\text { communal and } \\
\text { private feast }\end{array}$ \\
\hline
\end{tabular}




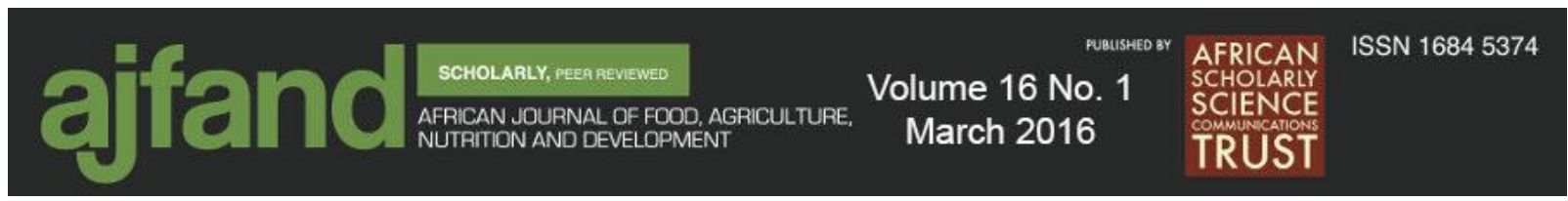

Table 1: continued-Animal handling and slaughter practices among Kenyan communities

\begin{tabular}{|c|c|c|c|}
\hline Kenyan & Method of slaugh & & Nature of \\
\hline & By females & By males & \\
\hline $\mathrm{Luo}^{5}$ & $\begin{array}{l}\text { Females or males } \\
\text { cut jugular vein } \\
\text { with a kitchen } \\
\text { knife }\end{array}$ & Cut jugular vein with a knife & $\begin{array}{l}\text { Domestic \& } \\
\text { communal feast } \\
\text { for community \& } \\
\text { others }\end{array}$ \\
\hline Kalenjin $^{5}$ & $\begin{array}{l}\text { Males cut the } \\
\text { jugular vein for } \\
\text { female users of } \\
\text { animal }\end{array}$ & $\begin{array}{l}\text { Cut the jugular vein of } \\
\text { animal with a sharp knife }\end{array}$ & $\begin{array}{l}\text { Communal \& } \\
\text { domestic feast } \\
\text { for community \& } \\
\text { others }\end{array}$ \\
\hline Kikuyu $^{5}$ & $\begin{array}{l}\text { Males cut jugular } \\
\text { vein of animal } \\
\text { for female users } \\
\text { of animal }\end{array}$ & $\begin{array}{l}\text { Cut jugular vein with a } \\
\text { kitchen knife }\end{array}$ & $\begin{array}{l}\text { Both communal } \\
\& \text { domestic feast } \\
\text { for community \& } \\
\text { others }\end{array}$ \\
\hline Kuria $^{5}$ & $\begin{array}{l}\text { Cuts though } \\
\text { jugular vein with } \\
\text { a kitchen knife }\end{array}$ & $\begin{array}{l}\text { On rare occasions females } \\
\text { smother animal to death } \\
\text { through suffocation, but } \\
\text { males normally cut jugular } \\
\text { vein on behalf of females }\end{array}$ & $\begin{array}{l}\text { Domestic \& } \\
\text { communal feast } \\
\text { for community \& } \\
\text { others }\end{array}$ \\
\hline
\end{tabular}

Legend-the numerals 1-5 are explained in the order 1-5 in the results section 


\section{REFERENCES}

1. National Coordinating Agency for Population and Development (NCPAD) Kenya Population Data Sheet. National Coordinating Agency for Population \& Development, Ministry of Planning, National Development and Vision 2030, Nairobi, 2011. Found at http://www.ncapd-ke.org/index.php?option=com_content\&view=article8. Accessed on 4th February, 2012.

2. Kenya National Bureau of Statistics (KNBS) Livestock statistics. Ministry of Planning, National Development and Vision 2030, Nairobi, 2011. Found at: http://www.knbs.or.ke/censuslivestock.php . Accessed on 20th January, 2012.

3. Lokuruka MNI The failure of the Norwegian-supported fish factory in Turkana, Kenya: an ecological-historical perspective. Egerton J. 2008c; Vol. II, No. 2 \& 3: 147-165.

4. $\quad$ FAO Livestock Information. Sector analysis and Policy Branch (AGAL), Food and Agriculture Organization of the UN, Rome, 2005a. Found at http://www.fao.org/ag/aginfo/resources/en/publications/sector_briefs/lsb-1. Accessed on 4th February, 2014.

5. Romans JR, Costello WJ, Carlson CW, Greaser ML and KW Jones The meat we eat, 4th edition. Interstate Publishers, Inc. Danville, Illinois, 2002.

6. KSPCA About us, our history. Kenya Society for the Protection and Care of Animals (KSPCA), Nairobi, 2012. Found at: http://www. Kspcakenya.org/about.htm. Accessed on 4th February, 2014.

7. Dawkins MS The science of animal suffering, Ethology 2008; 114(10): 937-945.

8. Gulliver PH The Family Herds: A study of two pastoral tribes in East Africa. The Jie and Turkana, 2nd Edition. Routledge \& Keagan Paul Ltd., London, 1966, $\mathrm{V} 1,1 \mathrm{X}$.

9. Pette $\mathbf{P}$ Mass animal sacrifice at Nepal festival goes ahead despite protests, November 14, Guardian Newspaper, London, 2014. Found at http://www.theguardian.com/world/2014/nov/28/mass-animal-sacrifice-nepalfestival-protests-gadhimai-hindu. Accessed on 22nd November, 2015.

10. Government of Kenya Meat Control (Inspection Fees) Regulations, 1974, Cap 356. Laws of Kenya. Found at:

http://www.kenyalaw.org:8181/exist/kenyalex/sublegview.xql?subleg=CAP.\%2 0356\#KE/LEG/EN/AR/M/CHAPTER\%20356/SUBLEG/HC_4. Accessed on 22nd November, 2015.

11. Cortesi ML Slaughterhouses and humane treatment. Rev. Sci. Tech. 1994; 13(I): 171-193. 


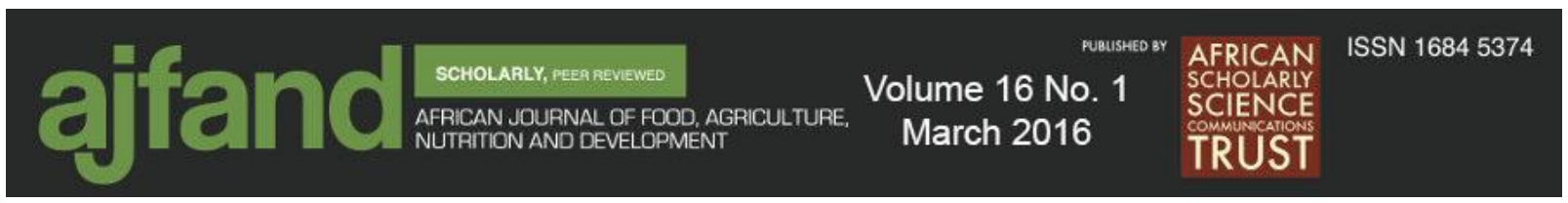

12. Appleby MC and BO Hughes Introduction. In: Animal Welfare. MC Appleby and BO Hughes (Eds.). CAB International, Wallingford, UK, 1997: 2-3.

13. European Union Council Decision 2004/544/EC of 21 June 2004 on the signing of the European Convention for the protection of animals during international transport (as amended) [Official Journal L 241 of 13.7.2004]. Found at www. http://www.eur-lex.europa.eu/legal-content/EN/TXT/?uri=URISERV:f83007. Accessed on 22nd November, 2015.

14. Garcia A, Pirner G, Guilherme P, May M, Guay K, Brittany B, Mhairi S and J McGlone Effect of provision of feed and water during transport on the welfare of weaned pigs. Animals (Basel) 2015; 5(2): 407-425. Published online 2015 Jun 4. doi: 10.3390/ani5020363, PMCID: PMC4494410. Accessed on $22^{\text {nd }}$ November, 2015.

15. Marques RS, Cooke RF, Francisco CL and DW Bohnert Effects of twentyfour hour transport or twenty-four hour feed and water deprivation on physiologic and performance responses of feeder cattle. J. Anim. Sci. 2012; 90(13): 50405046.

16. Gortel K, Young BA, Kawamoto SC and AL Schaefer Effects of transport stress and electrolyte supplementation on body fluids and weight of bulls. Can. J. Anim. Sci. 1992; 72(3): 547-553.

17. Wood JD, Holder JS and DCJ Main Quality assurance schemes. Proceedings of the International Congress of Meat Science and Technology (Barcelona, Spain), 1998; 44: 206-215.

18. Meisinger D A system for assuring pork quality. National Pork Producers Council, Des Moines, Iowa, USA, 1999: 1-10.

19. Belk EK, Scanga JA, Smith GC and T Grandin The relationship between good handling/stunning and meat quality in beef, pork and lamb. Presented at the American Meat Institute Foundation, Animal Handling and Stunning Conference on February 21-22, Fort Collins, Colorado, USA, 2002.

20. Smith GC and T Grandin Animal handling for productivity, quality and profitability. Presented at the Annual Convention of the American Meat Institute, 1998. Philadelphia, PA, USA.

21. Lokuruka MNI, Muyela B, Okeyo GO and A Shitandi Creating a grading scheme for fresh ice-stored White snapper (Lutjanidae spp.) and Rabbit fish (Siganus sutor) using quality indices. Egerton J. Sci. \& Technol. 2013; 13: 72 94.

22. Hale DS, Goodson $\mathbf{K}$ and JW Savell USDA beef quality and yield grades. Found at http://www.beef.tamu.edu/beefgrading/. Updated March 2013. Accessed on 29th December, 2015. 


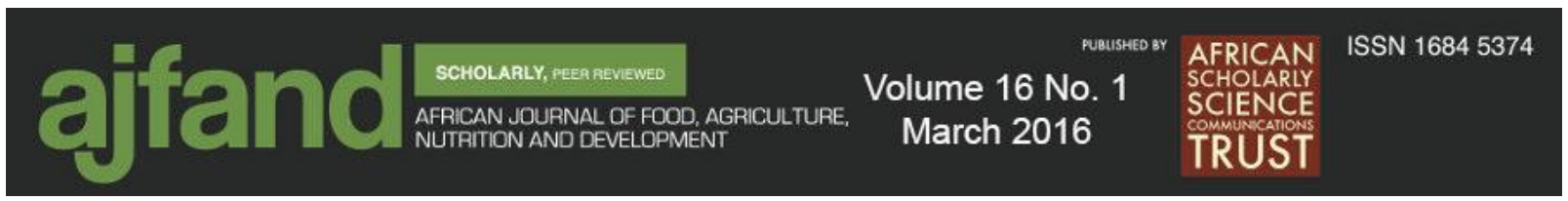

23. Henckel P, Karlsson AH, Oksbjerg N and PJ Søholm Control of post mortem $\mathrm{pH}$ decrease in pig muscle: experimental design and testing of animal models. Meat Science 2000; 55: 131-138.

24. Gallwey WJ and PV Tarrant Pre-slaughter stress affects pig meat quality. Farm Food Res 1978; 9: 30-32.

25. Hails MR Transportation stress in animals-A review. Animal Reg Stud 1978; 1: 289-343.

26. Rosenvold $\mathbf{K}$ and $\mathbf{H J}$ Andersen The significance of pre-slaughter stress and diet on colour and colour stability of pork. Meat Science 2003; 63: 199-209.

27. Peres LM, Bridi AM, da Silva CA, Andreo N, Tarsitano MA and ELT Stivaletti Effect of low or high stress in pre-slaughter handling on pig carcass and meat quality. Revista Brasileira de Zootecnia 2014; 43(7): 5010-12.

28. Leheska JM, Wulf DM and RJ Maddock Effects of fasting and transportation on pork quality development and extent of postmortem metabolism. J. Anim. Sci. 2002; 80(12): 3194-3202.

29. Adzitey F and H Nurul Pale soft and exudative (PSE) and dark firm dry (DFD) meats: causes and measures to reduce these defects-a mini review. Int. Food Res. J. 2011; 18: 11-20.

30. D'Eath RB, Turner SP, Kurt E, Evans G, Thölking L, Looft H, Wimmers K, Murani E, Klont R, Foury A, Ison SH, Lawrence AB and $\mathbf{P}$ Mormède Pigs aggressive temperament affects pre-slaughter mixing aggression, stress and meat quality. Animal 2010; 4: 604-616.

31. Warriss PD Meat Science-An Introductory text. CAB International, Wallingford, UK, 2000.

32. Muchenje V, Dzama K, Chimonyo M, Strydom PE, and JG Raats Relationship between pre-slaughter stress responsiveness and beef quality in three cattle breeds. Meat Science 2009; 81: 653-657.

33. Grandin T Recommended animal handling guidelines and audit guide for cattle, pigs, and sheep. American Meat Institute Foundation, Washington DC., 2010. Found at www.grandin.com/RecAnimalHandlingGuidelines.html. Accessed on $29^{\text {th }}$ December, 2015.

34. Russo VLN, Costa DP, Fiego L and A Pantano Influence of pre-slaughter resting time on carcass and ham quality in Italian heavy pigs. Proceedings of the International Congress of Meat Science and Technology (Barcelona, Spain) 1998; 44: 1062-1063. 


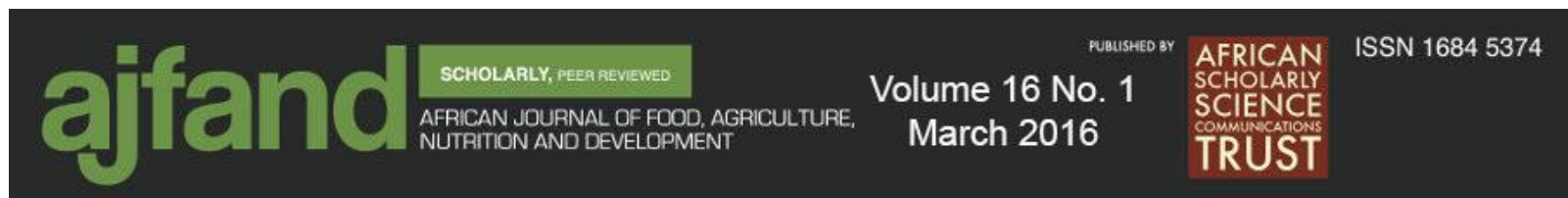

35. Mohamed B and I Mohamed The effects of residual blood of carcasses on poultry technological quality. Food and Nutrition Sciences 2012; 3(10): Article ID: 23386, 5 pages DOI:10.4236/fns.2012.310181.

36. Alvarado CZ, Richards MP, O'Keefe SFO and H Wang The effect of blood removal on oxidation and shelf life of broiler breast meat. Poultry Science 2007; 86(1): 156-161. 